\title{
Grazing intensity impacts on pasture carbon and nitrogen flow
}

\author{
V.S. BARON ${ }^{1 *}$, E. MAPFUMO ${ }^{2}$, A.C. DICK ${ }^{1}$, M.A. NAETH ${ }^{2}$, E.K. OKINE ${ }^{3}$ AND D.S. CHANASYK ${ }^{2}$
}

\begin{abstract}
${ }^{1}$ Research Scientist and Research Associate with Lacombe Research Centre, Agriculture and Agri-Food Canada, 6000 C\&E Trail, Lacombe, Alberta, Canada T4L IWl; ${ }^{2}$ Post-doctoral fellow with the Department of Renewable Resources, University of Alberta, Edmonton, Alberta, Canada T6G 2HI; and Professors with the Department of Renewable Resources, University of Alberta, Edmonton, Alberta, Canada T6G $2 \mathrm{H} 1 ;{ }^{3}$ Associate Professor with Department of Agriculture, Food and Nutritional Science, Agriculture and Forestry Centre, University of Alberta, Edmonton, AB, T6G 2P5. * Corresponding author (Email address: Baronv@agr.gc.ca. Contribution \#974.
\end{abstract}

\begin{abstract}
There is little information on the impact of grazing intensity on productivity and sustainability of intensively managed pastures in the humid, short-season parkland of the Canadian prairies. Our hypothesis was that above-ground productivity of dry matter, carbon, nitrogen, and in vitro digestible organic matter would be reduced proportionately with increasing grazing intensity. The study was conducted on a Typic Haplustoll at Lacombe, Alberta. Paddocks of meadow bromegrass (Bromus riparius Rhem.), replicated 4 times, were subjected to heavy, medium and light grazing intensities. Measurements and analyses were carried out for 3 years. Yields of dry matter, carbon, nitrogen, and in vitro digestible organic matter before and after grazing were determined and seasonal pools of above ground production, disappearance and residual were calculated. Concentrations of acid and neutral detergent fiber and lignin were also determined before and after grazing. Increasing grazing intensity tended to increase nitrogen and decrease fiber concentrations for available and residual forage. Heavy and medium grazing intensities produced 83 and $90 \%$ as much above ground dry matter and 87 and 90\% above ground carbon as the light intensity. All disappearance pools were similar among grazing intensities except in vitro digestible organic matter, where heavy was $116 \%$ of light. Heavy grazing reduced the contribution of vegetative dry matter, in vitro digestible organic matter, carbon and nitrogen to the residual to $41,50,36$, and $52 \%$ of that for light grazing. Adding estimated fecal-carbon to the residual significantly increased total residual carbon. Estimated fecal-carbon represented 68, 51, and $42 \%$ of all carbon inputs to litter for heavy, medium and light grazing, respectively. Grazing intensity did not affect estimated pools of excreted nitrogen, but increased estimated percent of nitrogen excreted as urine.
\end{abstract}

Key Words: nutrient flow, productivity, disappearance, residual, pasture, nutritive value

Funding for this research was provided by Canada-Alberta Environmentally Sustainable Agriculture Agreement. Support from Norwest Labs, Edmonton, AB is greatly appreciated. We thank David Young, Chris Meyers, and Pascal Ogle for technical assistance. The assistance of Drs. K.N. Harker and E.A. de St Remy in reviewing the manuscript is greatly appreciated.

Manuscript accepted 3 Jan. 02

\section{Resumen}

Hay poca información sobre el impacto de la intensidad de apacentamiento en la productividad y sustentabilidad de praderas manejados intensivamente en la región de las praderas húmedas de estación corta de Canadá. Nuestra hipótesis fue que la productividad aérea de materia seca, carbón, nitrógeno y materia orgánica digestible sería reducida proporcionalmente al incremento de la intensidad de apacentamiento. Este estudio se condujo en Lacombe, Alberta. Potreros de "Meadow bromegrass" (Bromus riparius Rhem.), repetidos 4 veces, se sometieron a intensidades de apacentamiento ligera, moderada y fuerte, las mediciones y análisis se condujeron durante 3 años. Los rendimientos de materia seca, carbón, nitrógeno y la materia orgánica digestible in vitro se determinaron antes y después del apacentamiento y se calcularon las reservas estacionales de la producción aérea, desaparición y del residuo, también se determinaron las concentraciones de fibra neutro y ácido detergente y de lignina. El aumento de la intensidad de apacentamiento tendió a incrementar la concentración de nitrógeno y a disminuir las concentraciones de fibra del forraje disponible y residual. Las intensidades de apacentamiento moderada y fuerte produjeron el 83 y $90 \%$ de la materia seca aérea y el 87 y $90 \%$ del carbón aéreo producidos con la intensidad ligera. Todas las cantidades de desaparición fueron similares entre las intensidades de apacentamiento, excepto materia orgánica digestible in vitro, la cual con el apacentamiento fuerte fue de $116 \%$ con respecto al apacentamiento ligero. EI apacentamiento fuerte redujo la contribución de materia seca vegetativa, materia orgánica digestible in vitro, carbón y nitrógeno del residuo en proporciones de 41, 50, 36, y 52\% de lo registrado con el apacentamiento ligero. Agregando la estimación del carbón fecal al residual incrementó significativamente el carbón total residual. El carbón fecal estimado representó el 68,51, y $42 \%$ de todas las entradas de carbón en el mantillo, para el apacentamiento fuerte, moderado y ligero respectivamente. La intensidad de apacentamiento no afectó las cantidades estimadas de nitrógeno excretado, pero incrementó el porcentaje estimado del nitrógeno excretado en la orina.

Managed intensive grazing is relatively new in the parkland vegetation zone of the Canadian prairies. The parkland has a short growing season, and is wetter and cooler than the southern prairies (Campbell et al. 1990), but is more productive. Despite 
the potential of intensive grazing, very little basic research has been conducted into its' effect on productivity, and subsequent impact on pasture and soil sustainability. Grazing per se and grazing intensity, in particular, affects productivity and nutritive value of pasture (Briske and Heitschmidt 1991, Wedin 1996), potential for pasture to sequester soil carbon (Schnabel et al. 2001), and for pasture soils to immobilize or mineralize $\mathrm{N}$ (Wedin 1996). Studying the flow of $C$ and $\mathrm{N}$ through pasture systems in response to varying grazing intensities, should provide information on potential impacts and limitations to long-term pasture sustainability.

Grazing and grazing intensity modify pasture production through effects on leaf area and light interception (Briske and Heitschmidt 1991, Lemaire and Chapman 1996). Generally, productivity is reduced as grazing intensity increases (Parsons et al. 1983, Matches 1992). It follows that the capacity for pastures to accumulate $C$, $\mathrm{N}$ and other nutrients above and below ground may be reduced with increased grazing intensity (Schnabel et al. 2001).

Grazing intensity affects the quantity and quality of organic and mineralized materials that are delivered to the litter and soil as vegetative residues, urine, and feces. As grazing intensifies so does seasonal utilization of pasture dry matter, C and $\mathrm{N}$ by livestock (Parsons et al. 1983, Briske and Heitschmidt 1991). Therefore the relative proportion of herbage material that passes directly to the litter via senescence, rather than indirectly via ruminant feces and urine is also affected (Parsons et al. 1983, Whitehead 1995, Lemaire and Chapman 1996).

Grazing also affects the quality of herbage in the sward and this ultimately impacts degradation rate of litter, soil organic matter, and soil nutrient mineralization rates (Wedin 1996). Generally, parameters used to describe nutritive value, such as crude protein and acid detergent fiber (ADF) concentrations have analogous parameters such as $\mathrm{C}: \mathrm{N}$ ratio and lignin concentration, which are closely related to microbial degradation of litter and soil organic matter (Wedin 1996, Schnabel et al. 2001). Improved grazing efficiency as a result of intensive grazing results in higher leaf to stem ratios (Parsons et al. 1983, Matches 1992) and less dead material left in the sward after grazing (Lemaire and Chapman 1996). Leaves have higher crude protein and lower ADF concentrations than stems at most stages of grass development (Baron et al. 2000), so leafy residues should degrade faster than stemy residues. Dead material has a higher $\mathrm{C}: \mathrm{N}$ ratio than live material, so residence time of organic- $\mathrm{C}$ in litter and soil pools is longer (Holland et al. 1992). Ultimately the quality of vegetative material moving from sward to litter pools affects quantity and residence time of $\mathrm{C}$ entering the soil pool (McGill et al. 1981, Holland et al. 1992, Wedin 1996, Schnabel et al. 2001).

Nutritive value of ingested herbage influences the fate of waste materials returned as feces and urine. For example, as $\mathrm{N}$ content of the sward increases a greater percentage of ingested- $\mathrm{N}$ is excreted as urine (Haynes and Williams 1993, Whitehead 1995), which then becomes susceptible to loss or plant uptake within a short time (McGill et al. 1981, Holland et al. 1992, Wedin 1996).

In this short-season area, plant growth and nutrient uptake is confined to a period of less than 100 days. Grazing can be intensified over shorter periods (within the window of plant growth) or extended to longer periods beyond the period of plant growth (e.g. 160 days). The pattern and intensity of nutrient flow from sward to litter will impact the quantity and quality of litter and the quantity and residence time of $\mathrm{C}$ in the soil, which ultimately affects pasture productivity and sustainability. The objectives of this study were: to determine the impact of grazing intensity on relative pool sizes of sward productivity, residual and disappearance dry matter $\mathrm{C}$, and $\mathrm{N}$; to determine the impact of grazing intensity on herbage and residual nutritive value; to estimate the impact of grazing intensity on proportional amounts of dry matter, $\mathrm{C}$ and $\mathrm{N}$ passed through a ruminant and returned to residual, compared to the vegetative contribution on a rotationally grazed meadow bromegrass (Bromus riparius $\mathrm{Rhem}$.) pasture, grown in a short season area.

\section{Materials and Methods}

\section{Experiment Establishment}

The study was established in 1993 at Lacombe, Alberta, Canada (52 $28^{\prime} \mathrm{N}$; $113^{\circ} 45^{\prime} \mathrm{W} ; 847 \mathrm{~m}$ ) on a Penhold silt loam (Typic Haplustoll) soil. In the spring the experimental area received a broadcast application of $8,14,26$, and $5 \mathrm{~kg} \mathrm{ha}^{-1}$ of $\mathrm{N}, \mathrm{P}, \mathrm{K}$, and $\mathrm{S}$, respectively, followed by a light cultivation and packing. Then 'Paddock' meadow bromegrass was hand broadcast at a rate of $16.8 \mathrm{~kg} \mathrm{ha}^{-1}$ mixed with $1 \mathrm{~kg} \mathrm{ha}^{-1}$ of Spredor II alfalfa (Medicago sativa L.). Seeding was followed by harrowing and packing. Each paddock was a fenced area of $9 \times 30 \mathrm{~m}$. Within each of 4 replicates, 3 paddocks (12 in total) were established for 3 grazing levels. All paddocks were hand weeded during the summer of 1993 and were grazed in late fall, but prior to freezing of the soil. Each spring (1994-1997), fertilizers to supply $100,22,42 \mathrm{~kg} \mathrm{ha}^{-1}$ of $\mathrm{N}, \mathrm{P}$, and $K$, respectively were broadcast over all paddocks. No herbicide was applied to the paddocks. By 1995 almost no alfalfa was present in the grazing treatments.

\section{Grazing Treatments}

Paddocks were grazed rotationally by yearling heifers from 1994 until 1997, with 3 grazing levels (GL) represented by different pre-grazing canopy heights. Canopy heights for grazing initiation were determined using the weighted disk method (Bransby et al. 1977). Target pregrazing heights were 13,17 , and $26 \mathrm{~cm}$ for heavy, medium, and light grazing levels, respectively. These heights were used to maintain consistency of grazing treatments, not to predict pasture yield. Grazing parameters are given in Table 1. From 2 to 6 heifers were placed in a paddock at a time and left for a period of no more than 24 hours to bring forage mass down to a desired residual mass for each treatment.

\section{Paddock Sampling.}

Detailed sampling for grass productivity and $\mathrm{C}$ and $\mathrm{N}$ flow was carried out during 1995, 1996, and 1997 on meadow bromegrass paddocks. For randomization of sampling, a grid with $2 \times 2$ m cells was superimposed on each paddock, with the perimeter of the grid $1 \mathrm{~m}$ from the outside on each side of the paddock. Three loca-

Table 1. Grazing management parameters for grazing intensity levels averaged over 1995, 1996, and 1997.

\begin{tabular}{|c|c|c|c|c|c|}
\hline Grazing level & First grazing & $\begin{array}{l}\text { Grazing } \\
\text { periods }\end{array}$ & $\begin{array}{c}\text { Total animal } \\
\text { days }\end{array}$ & $\begin{array}{c}\text { Mean animal } \\
\text { days }\end{array}$ & $\begin{array}{c}\text { Mean rest } \\
\text { period (days) }\end{array}$ \\
\hline & & \multicolumn{2}{|c|}{--.--(per season) -- } & \multicolumn{2}{|c|}{---------(per cycle)------ } \\
\hline Heavy & 28 May & 5.3 & 27.9 & 5.3 & 20.3 \\
\hline Medium & 01 June & 4 & 16.0 & 4.0 & 23.3 \\
\hline Light & 12 June & 3 & 14.4 & 4.8 & 51.3 \\
\hline
\end{tabular}


tions on the grid were chosen at random for each sampling period with the stipulation that each new sample area be at least 1 grid-square away from the one used in the previous harvest. Within a grid-square, 2 stakes were placed at random to mark sampling areas. Prior to and after grazing periods, a rectangular frame $(25 \times 50-\mathrm{cm})$ was placed with one corner against the marker stake and the herbage inside the frame was cut $2.5 \mathrm{~cm}$ above the soil surface. All of the harvested herbage from each paddock was bulked, weighed fresh and then subsampled for determination of dry matter, $\mathrm{C}, \mathrm{N}$, in vitro digestible organic matter (IVDOM), acid (ADF) and neutral detergent fiber (NDF), and lignin concentrations.

Leaf area index (LAI) was measured before and after grazing periods in 1995 and 1996 using a LAI-2000 plant canopy analyzer consisting of a LAI-2050 optical sensor (Li-Cor Ltd., Lincoln, Nebr.). Ten readings, taken at random, at least $1 \mathrm{~m}$ from the edge of each paddock were averaged by the instrument.

\section{Chemical and Biological Composition}

Herbage sub-samples (250 g), taken before and after grazing to be used for determination of dry matter concentration were weighed fresh and dried at $80^{\circ} \mathrm{C}$ for 72 hours. Similar sub-samples (250 g) taken before and after grazing to be used for determination of forage quality and $\mathrm{C}$ composition were dried at $50^{\circ} \mathrm{C}$ for 72 hours. These were ground, first through a Wiley mill (Model no. 4; Arthur H. Thomas Co., Philadelphia, Penn.) equipped with a $2-\mathrm{mm}$ screen and then through a Cyclone mill (Model MS; UD Corporation, Boulder, Colo.) using a 1.0$\mathrm{mm}$ screen, prior to quality determinations. The samples were analyzed for total $\mathrm{N}$ concentration by a micro-Kjeldahl technique (Wall and Gerke 1975) and an auto analyzer system (industrial method no. 786-86T. Bran \& Luebbe INC, Tarrytown, N.Y., 10591-5097). Crude protein concentration was calculated as $6.25 \mathrm{x} \mathrm{N}$ concentration. In vitro digestible organic matter concentration (IVDOM) was measured with direct acidification during a 24 hour second stage pepsin digestion (Marten and Barnes 1980). Neutral detergent fiber, ADF and permanganate lignin (lignin) concentrations were determined sequentially (Van Soest and Robertson 1980). Total C was measured with a Leco Carbon Determinator (Model CN 2000, Leco Corp., St. Joseph, Mich.).

\section{Derived Variables}

Available herbage and residual yields were calculated for pre- and post-grazing, respectively. Seasonal pools of above ground productivity, disappearance and the vegetative component of the residual for dry matter, C, N, and IVDOM were determined by a method similar to that described by Singh et al. (1975) as:

$$
\begin{aligned}
& A P=A_{1}+\sum_{\mathrm{i}=1}^{\mathrm{n}}\left(A_{i+1}-R_{1}\right) \\
& D P=\sum_{\mathrm{i}=1}^{\mathrm{n}}\left(A_{1}-R_{1}\right) \\
& V R=A P-D P
\end{aligned}
$$

where seasonal above ground productivity (1), disappearance (2), and vegetative residual (3) were calculated from A, available herbage mass, and $\mathrm{R}$, residual, determined before and after each grazing period (i), respectively. Corresponding values for $\mathrm{C}, \mathrm{N}$, and IVDOM were determined by multiplying the $\mathrm{C}, \mathrm{N}$, and IVDOM concentration at each grazing period for available herbage and residue by the respective paddock dry matter yield and summing over the season as indicated for above ground productivity, disappearance, and vegetative residue.

Fecal $\mathrm{C}$ (which is deposited in the litter) was estimated by partitioning disappearance $\mathrm{C}$ into digested $\mathrm{C}$ and fecal $\mathrm{C}$. Digested $\mathrm{C}$ was determined by multiplying the IVDOM concentration of herbage mass at each grazing period by the $\mathrm{C}$ disappearance from each grazing period. This was summed over the season as for disappearance. Then fecal $\mathrm{C}$ was the difference between disappearance $\mathrm{C}$ and digested $\mathrm{C}$.

Excreted $\mathrm{N}$ of growing cattle was assumed to be $90 \%$ of $\mathrm{N}$ disappearance (Whitehead 1995). To partition $\mathrm{N}$ excreted in urine and fecal- $\mathrm{N}$, percent $\mathrm{N}$ excreted in urine at each grazing period was estimated from the generalized equation below (Whitehead 1995):

$\% \mathrm{~N}$ excreted in urine $=45+14 \mathrm{x}$

$$
(\% \mathrm{~N} \text { in herbage mass }-1.0)
$$

Urine $\mathrm{N}$ was estimated by multiplying the fraction times $\mathrm{N}$ disappearance for that grazing period, summing over grazing periods within the season. Fecal-N excreted was estimated by subtracting urine $\mathrm{N}$ from excreted $\mathrm{N}$ for the season.

\section{Statistical Analyses}

Data shown for LAI were analyzed as averages over grazing cycles within each paddock and year. Data for chemical and biological composition of available herbage (before grazing) and residual (after grazing) were analyzed statistically as weightedmeans of all grazing periods within paddocks and years. Data were subjected to analysis of variance using the SAS GLM procedure (SAS Institute 1989) with a splitplot model. Grazing levels (GL) were main plot effects tested for significance using replication (GL) as the error term, years (repeated measures) were a subplot factor and the interactions were tested with the residual error (Steel and Torrie 1980). Where the F-test indicated a significant ( $\mathrm{P}$ $\leq 0.05$ ) effect, means were separated by LSMEANS using the appropriate error mean squares (SAS Institute 1989).

\section{Results and Discussion}

Precipitation from April to October was high in all 3 years, ranging from $106 \%$ in 1996 to $146 \%$ above the long-term average $(362 \mathrm{~mm})$ in 1997 , although intermittent dry periods occurred as in August of 1996. Long term average mean temperatures for June, July, August, and September are 13.6, 16.1, 16.0, and $14.6^{\circ} \mathrm{C}$, respectively. Average mean temperatures for these months were usually average to below average during summers of all 3 years.

\section{Productivity}

Heavy, medium, and light grazing intensities were subjected to 5, 4 and 3 grazing periods, respectively per season (Table 1). Average rest periods for light were approximately 2.5 times longer than for heavy. Commercial intensive grazing operations in the area might graze 2 to 3 times and occasionally 4 times under conditions of

\begin{tabular}{|c|c|c|c|c|}
\hline & Heavy & $\begin{array}{l}\text { zing inten } \\
\text { Medium }\end{array}$ & Light & Mean \\
\hline & \multicolumn{4}{|c|}{$\left(\mathrm{cm}^{2} \mathrm{~cm}^{-2}\right)$} \\
\hline Before grazing & $3.07 \mathrm{c}^{\dagger}$ & $3.53 b$ & $5.04 \mathrm{a}$ & 3.88 \\
\hline After grazing & $1.42 \mathrm{a}$ & $1.46 \mathrm{a}$ & $1.52 \mathrm{a}$ & 1.47 \\
\hline
\end{tabular}
high pasture growth, rainfall and soil fertil-

Table 2. Seasonal mean leaf area index before and after grazing meadow bromegrass pastures at 3 intensities averaged over grazing periods and 2 years (1995 and 1996). 
Table 3. Weighted mean concentrations of in vitro digestible organic matter, neutral detergent fiber, acid detergent fiber, lignin, and protein for available herbage and residual mass from meadow bromegrass pastures grazed at 3 intensities averaged over 3 years $(1995,1996$, and 1997).

\begin{tabular}{|c|c|c|c|c|c|}
\hline Grazing intensity & IVDOM $^{\dagger}$ & $\mathrm{NDF}$ & $\overline{\mathrm{ADF}}$ & Lignin & Protein \\
\hline & \multicolumn{5}{|c|}{ - Available Herbage (before grazing) $\left(\mathrm{g} \mathrm{kg}^{-1}\right)$--- } \\
\hline Heavy & $759 a^{\ddagger}$ & $474 b$ & $253 b$ & $33.2 \mathrm{~b}$ & $210 \mathrm{a}$ \\
\hline Medium & $710 \mathrm{~b}$ & $522 \mathrm{a}$ & $284 \mathrm{ab}$ & $37.0 \mathrm{ab}$ & $182 b$ \\
\hline Light & $688 \mathrm{~b}$ & $535 \mathrm{a}$ & $301 \mathrm{a}$ & $41.2 \mathrm{a}$ & $168 b$ \\
\hline \multirow[t]{2}{*}{ Mean } & 720 & 510 & 279 & 37.0 & 187 \\
\hline & \multicolumn{5}{|c|}{--1.-- Vegetative Residual (after grazing) $\left(\mathrm{g} \mathrm{kg}^{-1}\right)$} \\
\hline Heavy & $694 a^{\ddagger}$ & $502 c$ & $269 c$ & $56.7 \mathrm{a}$ & $169 a$ \\
\hline Medium & $685 a$ & $549 \mathrm{~b}$ & $300 \mathrm{~b}$ & $51.4 \mathrm{a}$ & $164 a$ \\
\hline Light & $650 \mathrm{~b}$ & $575 a$ & $322 a$ & $53.4 \mathrm{a}$ & $152 b$ \\
\hline Mean & 676 & 542 & 297 & 53.5 & 161 \\
\hline
\end{tabular}

IVDOM is in vitro digestible organic matter, NDF is neutral detergent fiber, and ADF is acid detergent fiber.

${ }^{\ddagger}$ Within columns, values followed by different letters are significantly different $(\mathrm{P} \leq 0.05)$ according to LSMEANS test in SAS.

ity, which occurred in the current study.

Efficient pasture production has been reported on perennial ryegrass (Lolium perenne L.) pastures in Europe over a range of LAI between 2 and $4 \mathrm{~cm}^{2} \mathrm{~cm}^{-2}$, when managed under continuous or rotational grazing (Lemaire and Chapman 1996). Despite higher than normal grazing intensities seasonal average LAI prior to grazing ranged from 3.0 to $5.0 \mathrm{~cm}^{2} \mathrm{~cm}^{-2}$ for heavy to light grazing intensities (Table 2). There was no difference among grazing intensities for LAI after grazing. The LAI following grazing would not have been considered low by standards of other studies, where residual LAI were below $1.0 \mathrm{~cm}^{2} \mathrm{~cm}^{-2}$ (Korte et al. 1982, Parsons et al. 1983).

The nutritional qualities of available herbage before and after grazing are shown in Table 3. Available herbage for heavy grazing had greater nutritional value than light for all parameters shown, while medium was intermediate. Also, medium and light grazing intensities were similar for all of these parameters. However, pregrazing ADF and lignin for medium were similar to both light and heavy grazing treatments. With the exception of weighted-mean lignin concentration nutritive value of residue following grazing was higher for heavy than for light grazing. However, unlike available herbage, residue of the medium intensity had higher IVDOM and protein and lower NDF and ADF concentrations than light (Table 3). Nutritive values for heavy, medium and light intensities, based on weighted-means for available herbage could support average daily gains for growing steers of 1.03, 0.80 and $0.74 \mathrm{~kg} \mathrm{day}^{-1}$ if consumption was as predicted from NDF concentration of the available forage (NRC 1996).

Above-ground productivity of the heavy and medium grazing treatments were $83 \%$ and $90 \%$ of the light grazing intensity, respectively for dry matter, and $87 \%$ and $90 \%$, respectively for C (Table 4). Above ground productivity of IVDOM and $\mathrm{N}$ were similar among grazing intensities (Table 4). The C: $\mathrm{N}$ ratio of above ground production was higher for light than other grazing intensities (Table 4).

Magnitudes of above ground productivity of dry matter and C were remarkably close among grazing intensities, even though light and heavy intensities were significantly different $(\mathrm{P} \leq 0.05)$. The results were in general agreement with those of Parsons et al. (1983) who found shoot and gross photosynthesis increased from heavy to light grazing. Generally, gross production increases with increasing LAI (Lemaire and Chapman 1996).

However, in Europe, dry matter production was relatively more efficient per unit LAI when swards were severely defoliated with short rest periods, than when allowed to attain a large LAI over rest periods longer than 20 days (Parsons et al. 1983, 1988, Parsons and Penning 1988).

The weighted mean above ground productivity for $\mathrm{N}$ and IVDOM reflect differences among treatments, where the higher $\mathrm{N}$ and IVDOM concentrations of the heavy grazing treatment compensate for a lower above ground production of dry matter, with the reverse apparent for the light grazing intensity (Table 3 ).

\section{Disappearance}

Disappearance of dry matter, C, and N, and the $\mathrm{C}$ : $\mathrm{N}$ ratio were similar among grazing intensities (Table 4). However, this was the result of seasonal utilization of above ground production of dry matter of approximately 83,73 , and $66 \%$ for heavy, medium, and light grazing treatments, respectively (data not shown). Ranges among grazing intensities for seasonal utilization of above ground production of $\mathrm{N}, \mathrm{C}$, and IVDOM were comparable. By contrast, IVDOM disappearance was significantly higher for heavy compared to light grazing intensity, with medium being intermediate. Parsons et al. (1983) observed greater intakes of dry matter from hard compared to leniently grazed treatments. Defoliation was more severe than in our current study.

Mean utilization rate for specific graz-

Table 4. Seasonal above ground productivity, disappearance and residual dry matter, in vitro digestible organic matter, $\mathrm{C}$ and $\mathrm{N}$ from meadow bromegrass pastures grazed at 3 intensities averaged over 3 years $(1995,1996$, and 1997).

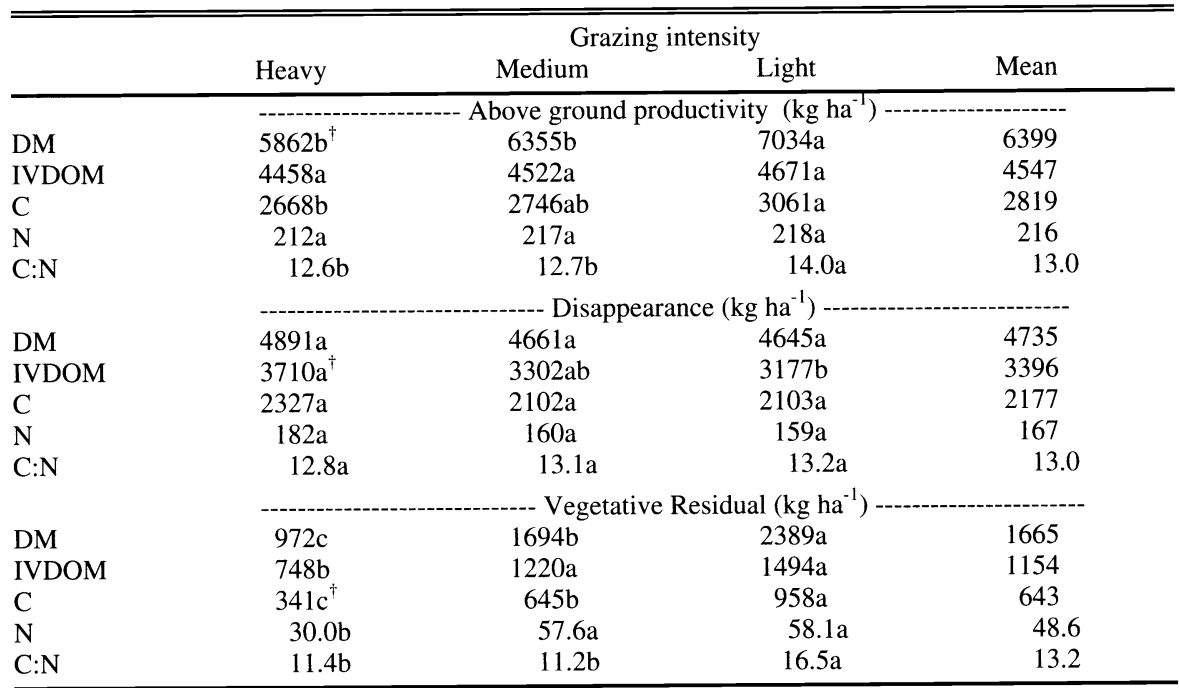

Within rows, values followed by different letters are significantly different ( $\mathrm{P} \leq 0.05)$ according to LSMEANS test in SAS.

DM is dry matter, IVDOM is in vitro digestible organic matter, $\mathrm{C}$ is carbon, and $\mathrm{N}$ is nitrogen. 
Table 5. End of season residual dry matter, carbon $(\mathrm{C})$ and nitrogen $(\mathrm{N})$ mass and $\mathrm{C}: \mathrm{N}$ ratio left in meadow bromegrass pastures subjected to 3 grazing intensities for 3 years $(1995,1996$, and 1997).

\begin{tabular}{|c|c|c|c|c|}
\hline & \multicolumn{4}{|c|}{ Grazing intensity } \\
\hline & Heavy & Medium & Light & Mean \\
\hline & $-\cdots$ & Dry & $-1)$ & $\begin{array}{c}----- \\
---\end{array}$ \\
\hline 1995 & $452 a$ & $908 \mathrm{a}$ & $1348 \mathrm{a}$ & 902 \\
\hline 1996 & $1095 b^{\dagger}$ & $3034 a$ & $2896 a$ & 2342 \\
\hline 1997 & $492 \mathrm{c}$ & $773 b$ & $1759 a$ & 1430 \\
\hline Mean & 680 & 1572 & 2001 & 1558 \\
\hline 1995 & $186 \mathrm{~b}$ & $364 b$ & $730 \mathrm{a}$ & 427 \\
\hline 1996 & $481 \mathrm{~b}$ & $1213 a$ & $955 a$ & 883 \\
\hline 1997 & $260 \mathrm{~b}$ & $321 b$ & $864 a$ & 482 \\
\hline Mean & 309 & 633 & 850 & 597 \\
\hline 1995 & $12.9 \mathrm{a}$ & $21.6 \mathrm{a}$ & $30.7 \mathrm{a}$ & 21.7 \\
\hline 1996 & $26.3 b$ & $75.7 \mathrm{a}$ & $62.8 \mathrm{a}$ & 54.9 \\
\hline 1997 & $11.4 \mathrm{~b}$ & $17.4 \mathrm{~b}$ & $43.1 \mathrm{a}$ & 24.0 \\
\hline Mean & 16.9 & 38.2 & 45.5 & 33.5 \\
\hline 1995 & $14.4 \mathrm{~b}$ & $16.9 \mathrm{~b}$ & $23.8 \mathrm{a}$ & 18.4 \\
\hline 1996 & $18.3 \mathrm{a}$ & $16.0 \mathrm{~b}$ & $15.2 \mathrm{~b}$ & 16.5 \\
\hline 1997 & $22.8 \mathrm{a}$ & $18.4 \mathrm{~b}$ & $20.0 \mathrm{ab}$ & 20.4 \\
\hline Mean & 18.5 & 17.1 & 19.7 & 18.4 \\
\hline
\end{tabular}

${ }^{\mp}$ Within rows, values followed by different letters are significantly different $(\mathrm{P} \leq 0.05)$ according to LSMEANS test in SAS.

ing periods was highly variable (data not shown) over years and grazing intensities. Percent utilization per grazing period was $42 \%$ of available herbage dry matter when averaged over years, grazing intensities and grazing cycles. This utilization rate compared favorably with the 40-50\% reported by Heitschmidt et al. (1987), although experimental set up was quite different from the current study. The former study found animal density did not consistently affect utilization of available herbage under rotational grazing systems. In the current study, greater grazing frequency for heavy and medium compared to light grazing harvested leaf material before it died and sceneced, resulting in relatively high seasonal dry matter disappearance. There was also little stem formation in these treatments.

\section{Vegetative Component of Residual}

Vegetative material moving directly to the litter was calculated from above ground productivity minus disappearance. Grazing intensity affected all fractions of vegetative residue significantly $(P \leq 0.05)$, but not identically (Table 4). Vegetatitive residual dry matter, IVDOM, C, and $\mathrm{N}$ left after disappearance were $41,50,36$, and $52 \%$ for the heavy compared to the light grazing intensity. One extra grazing cycle (medium) beyond normal (light) reduced dry matter and $\mathrm{C}$ residuals to $71 \%$ and $80 \%$ of the light intensity. Heavy grazing allowed only $13 \%$ of above ground pro- duction of $\mathrm{C}$ and $14 \%$ of above ground production of $\mathrm{N}$ to move directly to litter compared to $31 \%$ of above ground production of $\mathrm{C}$ and $27 \%$ of above ground production of $\mathrm{N}$ for light grazing.

Parsons et al. (1983) reported that reduced residue for hard compared to lenient grazing, was due to removal of a higher percentage of shoot material as it formed, resulting in no tissue death and little accumulation of stem material, which impeded grazing in the lenient grazing treatment. However, under semi-arid range conditions high vs. low stocking density had little impact on grazing efficiency (Heitshmidt et al. 1987).

Year-end residuals, estimated and actual (live and dead standing biomass), determined in the fall, were affected by year $\mathrm{x}$ GL interactions (Table 5). However, the same general trends with grazing intensity are evident in both residuals (Tables 4 and 5) for dry matter, $\mathrm{C}$ and $\mathrm{N}$ pools. Averaged over years, actual, year-end dry matter, $\mathrm{C}$ and $\mathrm{N}$ residuals (Table 5) are

Table 6. Estimated annual digested, fecal and residual plus fecal-C from meadow bromegrass pastures grazed at 3 intensities averaged over 3 years $(1995,1996$, and 1997).

\begin{tabular}{|c|c|c|c|c|}
\hline & \multicolumn{4}{|c|}{ Grazing intensity } \\
\hline & Heavy & Medium & Light & Mean \\
\hline & $-\cdots$ & - & $\begin{array}{l}+-\cdots \\
-\cdots-\cdots\end{array}$ & - \\
\hline Digested-C & $1602 \mathrm{a}$ & $1432 b$ & $1419 b$ & 1484 \\
\hline Fecal-C & $725 a$ & $669 a$ & $684 a$ & 693 \\
\hline Residue + fecal $-\mathrm{C}$ & $1066 c$ & $1314 b$ & $1626 a$ & 1336 \\
\hline
\end{tabular}

${ }^{\mp}$ Within rows, values followed by different letters are significantly different $(\mathrm{P} \leq 0.05)$ according to LSMEANS test in SAS. numerically smaller than estimated residuals (Table 4). Heavy grazing dry matter, $\mathrm{C}$ and $\mathrm{N}$ residues were proportionately smaller than medium and light grazing intensities. Three-year average, actual, year-end residues (Table 5) ranged from 89 to $98 \%$ for C, 69 to $92 \%$ for dry matter and 56 to $78 \%$ for $\mathrm{N}$ compared to estimated counterparts (Table 4). Reasons for differences between estimated and actual residuals are speculative. Error in measurement or estimation of residuals is acknowledged and may have been high. There is evidence in the literature (Wedin 1996, Lemaire and Chapman 1996) to indicate that plant materials of the nature (i.e. high $\mathrm{N}$ concentration and narrow $\mathrm{C}$ : $\mathrm{N}$ ratio) found in the heavily grazed residue may mineralize rapidly. However, there is no certainty that this was the cause for discrepancy between actual and estimated residual pools for the heavy grazing treatment in this study.

\section{Residues from Animal Waste}

Animal wastes were not measured directly, but estimates are important because urine and feces are components of $\mathrm{C}$ and $\mathrm{N}$ flow to litter and soil in a more mineralized form than vegetative material and cycle more rapidly than vegetative material (McGill et al. 1981, Lemaire and Chapman 1996, Wedin 1996). Estimated fecal-C was not affected by grazing intensity. Estimated fecal-C represented 68, 51, and $42 \%$ of all residual-C flowing back to litter and soil for heavy, medium, and light grazing intensities respectively, not including root and below ground litter material. However when estimated fecal-C was added to vegetative residue, grazing intensities were significantly different from one another for total residual-C (Table 6). Adding estimated fecal-C to the vegetative residue substantially increased C deposition to the litter. For example, considering only the vegetative residual component, $\mathrm{C}$-inputs to the litter from the heavy and medium grazing intensities were 36 and $67 \%$ of the light grazing intensity, respectively. Addition of fecal-C to vegetative residual- $\mathrm{C}$ increased $\mathrm{C}$ - 
Table 7. Estimates of total annual consumed, excreted and excreted plus residual- $\mathrm{N}$ and percentage of excreted- $\mathrm{N}$ in urine from meadow bromegrass pastures grazed at 3 intensities averaged across 3 years.

\begin{tabular}{lcccc}
\hline \hline & \multicolumn{4}{c}{ Grazing intensity } \\
& Heavy & Medium & Light & Mean \\
\hline & $176 \mathrm{a}$ & $180 \mathrm{a}$ & $179 \mathrm{a}$ & 178 \\
Consumed-N & $149 \mathrm{a}$ & $153 \mathrm{a}$ & $152 \mathrm{a}$ & 151 \\
Excreted-N & $179 \mathrm{a}$ & $211 \mathrm{a}$ & $210 \mathrm{a}$ & 200 \\
$\begin{array}{l}\text { Vegetative residue } \\
\text { plus excreted N }\end{array}$ & & & & \\
Urinary-N & $104 \mathrm{a}$ & $101 \mathrm{a}$ & $96 \mathrm{a}$ & 101 \\
Fecal-N & $45 \mathrm{a}$ & $52 \mathrm{a}$ & $56 \mathrm{a}$ & 51 \\
$\%$ excreted N in urine & $71.2 \mathrm{a}$ & $64.8 \mathrm{~b}$ & $61.7 \mathrm{~b}$ & 65.9 \\
\hline
\end{tabular}

${ }^{\dagger}$ Within rows, values followed by different letters are significantly different $(\mathrm{P} \leq 0.05)$ according to LSMEANS test in SAS.

inputs to the litter from the heavy and medium grazing intensities to $66 \%$ and $80 \%$ of the light grazing intensity, respectively. Increasing grazing cycles beyond 3 resulted in the majority of $\mathrm{C}$ deposited to litter as mineralized vs. vegetative.

The literature varies as to percentage of $\mathrm{N}$ retained by beef animals. Values range from 5 to $15 \%$ for growing animals (Whitehead 1995, Mathews et al. 1996) up to $25 \%$ for lactating cows (Whitehead 1995, Mathews et al. 1996). Excreted-N was estimated using a factor of $10 \%$ retention by the animal (Whitehead 1995). All categories of $\mathrm{N}$ totaled were similar across grazing intensities, except for percent $\mathrm{N}$ excreted as urine (Table 7). In the latter case, heavy had higher values than medium and light grazing intensities reflecting higher protein concentrations in available forage for heavy relative to the other grazing intensities (Table 3). Amounts of urine-N excreted per acre would have been double fecal-N. This could affect loss of $\mathrm{N}$ as loss of urinary $\mathrm{N}$ through volatilization is much greater than fecal-N and dependent on environmental conditions (Whitehead 1995). The proportion of total $\mathrm{N}$ returned to the paddock by excretion was $83 \%$ for heavy, compared to $73 \%$ and $72 \%$ for medium and light grazing, respectively. Because excreted $\mathrm{N}$ is in more mineralized form than vegetative $\mathrm{N}$, the rate of $\mathrm{N}$ cycling through the soil-plant-animal system would likely be greater for the heavy grazing treatment compared to the medium and light treatments.

\section{Summary}

The flow of $\mathrm{C}$ and $\mathrm{N}$ from sward to litter is dictated by the size of above ground productivity and it's partitioning into disappearance, vegetative and animal waste residual products. We hypothesized that the size of above ground productivity, disappearance and vegetative residue would be reduced proportionately as grazing intensity increased. This did not occur. The size of above ground productivity was reduced significantly $(\mathrm{P}<0.05)$, but only slightly when meadow bromegrass was exposed to heavy vs. light (5 vs. 3 cycles per season) grazing intensities; disappearance was not reduced by grazing intensity. The consequence was that the vegetative residual component was reduced proportionately more than above ground productivity from light to heavy grazing. In concert with disappearance, fecal-C did not vary with grazing intensity, but when added to vegetative residual- $C$ increased total residual-C substantially. Fecal-C represented a much higher percentage of the total residual-C in the heavy $(68 \%)$ than in the light $(42 \%)$ grazing intensity. Percent $\mathrm{N}$, excreted as urine, was higher for heavy than for light grazing. Also the residue ligno-cellulose (ADF) concentration was lower, IVDOM and protein concentrations higher for heavy and medium than light grazing. It is generally accepted that vegetative materials, which move directly to litter degrade and recycle nutrients more slowly than materials that have passed through ruminants on pasture (Briske and Heitschmidt 1991, Holland et al 1992, Haynes and Williams 1993, Whitehead 1995, Lemaire and Chapman 1996, Wedin 1996). Thus, grazing intensity could have large implications to sustainability and productivity in intensive pastures systems in a short-season area.

\section{Literature Cited}

Baron, V.S., A.C. Dick, and J.R. King. 2000. Leaf and stem mass characteristics of coolseason grasses grown in the Canadian parkland. Agron. J. 92:54-63.

Bransby, D.I., A.G. Matches, and G.F. Krause. 1977. Disk meter for rapid estimation of herbage yield in grazing trials. Agron. J. 69:393-396.
Briske, D.D. and R.K. Heitschmidt. 1991. An ecological perspective, p. 7-2. In R.K. Heitchmidt and J.W. Stuth. (eds.), Grazing management: an ecological perspective. Timber Press, Portland, Ore.

Campbell, C.A., R.P. Zentner, H.H. Janzen, and K.E. Bowren. 1990. Crop rotation studies on the Canadian prairies. Research Branch, Agr. Canada. Pub. No. 1841/E 133 p

Haynes, R.J. and P.H. Williams. 1993. Nutrient cycling and soil fertility in the grazed pasture ecosystem. Adv. in Agron. 49:119-199.

Heitschmidt, R.K., S.L. Dowhawer, and J.W. Walker. 1987. 14- vs. 42-paddock rotational grazing: aboveground biomass dynamics, forage production and harvest efficiency. J. Range Manage. 40:216-223.

Holland, E.A., W.J. Parton, J.K. Detling, and L. Coppock. 1992. Physiological responses of plant populations to herbivory and their consequences for ecosystem nutrient flow. Amer. Naturalist. 140:685-706.

Korte, C.J., B.R. Watkin, and W. Harris. 1982. Use of residual leaf area index and light interception as criteria for spring-grazing management of a ryegrass dominant pasture. N.Z.J. Agr. Res. 25: 309-319.

Lemaire, G. and D. Chapman. 1996. Tissue flows in grazed plant communities, p. 3-36. In: J. Hodgson and A.W. Illius (eds.), The ecology and management of grazing systems. CAB International, Wallingford, Oxon, U.K.

Marten, G.C. and R.F. Barnes. 1980. Prediction of energy digestibility of forages and fungal enzyme systems. p. 61-71. In: W.J. Pigden et al. (eds.), Standardization of analytical methodology for feeds. IDRC134e. Ottawa, Ontario.

Mathews, B.W., L.E. Sollenberger, and J.P. Tritschler II. 1996. Grazing systems and spatial distribution of nutrients in pastures: soil considerations. p. 213 to 226 In: R.E. Joost and C.A. Roberts (eds.), Proc. Sym. March 7-8, 1996 Columbia, MO Potash and Phosphate Institute and the Foundation for Agronomic Research, Manhattan, Kans.

Matches, A.G. 1992. Plant response to grazing: a review. J. Prod. Agr. 5:1-7.

McGill, W.B., H.W. Hunt, R.G. Woodmansee, and J.O. Ruess. 1981. Phoenix, a model of the dynamics of carbon and nitrogen in grassland soils. Ecol. Bull. (Stockholm) 33:49-11

NRC 1996. Nutrient requirements of beef cattle. Seventh ed. National Academy Press. Washington, DC

Parsons, A.J. and P.D. Penning. 1988. The effect of the duration of regrowth on photosynthesis, leaf death and the average rate of growth in a rotationally grazed sward. Grass and Forage Sci. 43:15-27.

Parsons, A.J., J.R. Johnson, and A. Harvey 1988. Use of a model to optimize the interaction between frequency and severity of intermittant defoliation and to provide a fundamental comparison of the continuous and intermittant defoliation of grass. Grass and Forage Sci. 43:49-59. 
Parsons, A.J., E.L. Leafe, B. Collett, P.D. Penning and J. Lewis. 1983. The physiology of grass production under grazing II. Photosynthesis, crop growth and animal intake of continuously-grazed swards. J. App. Ecol. 20:127-139.

SAS Institute. 1989. User's Guide: Statistics. Version 6. SAS Inst., Cary N.C.

Schnabel, R.R., A.J. Franzluebbers, W.L. Stout, M.A. Sanderson, and J.A. Steudeman. 2001. The effects of pasture management practices. p. 291-322. In: R.F. Follet, J.M. Kimble and R. Lal (eds.). The potential of U.S. grazing lands to sequester carbon and mitigate the greenhouse effect. Lewis Publishing, Boca Raton, Fla.
Singh, J.S., W.K. Laurenroth, and R.K. Steinhorst. 1975. Review and assessment of various techniques for estimating net aerial primary production in grasslands from harvest data. Bot. Rev. 41:182-232.

Steel, R.G.D. and J.H., Torrie. 1980 . Principles and procedures of statistics: a biometrical approach. $2^{\text {nd }}$ ed. McGraw-Hill, N.Y. 633 pp.

Van Soest, P.J. and J. B. Robertson. 1980. Systems analyses for evaluation of fibrous feeds. p 49-60. In: W.J. Pigden et al. (eds.), Standardization of analytical methodology for feeds. IDRC-134e. Ottawa, Ontario.
Wall, L.L. and G.W Gerke. 1975. An automated total protein nitrogen method. J. Assoc. Off. Anal. Chem. 58:1221-1226.

Wedin, D.A. 1996. Nutrient cycling in grasslands: An ecologist's perspective. p. 29-44 In: R.E. Joost and C.A. Roberts (eds.) Nutrient cycling in forage systems. Proc. Sym. March 7-8, 1996 Columbia, MO 'Potash and Phosphate Inst. and the Found. for Agron. Research, Manhattan, Kans.

Whitehead, D.C., 1995. Consumption, digestion and excretion of nitrogen by ruminant livestock p. 59-81. In: D.C. Whitehead (ed.), Grassland Nitrogen. CAB. International, Wallingford, Oxon, U.K.

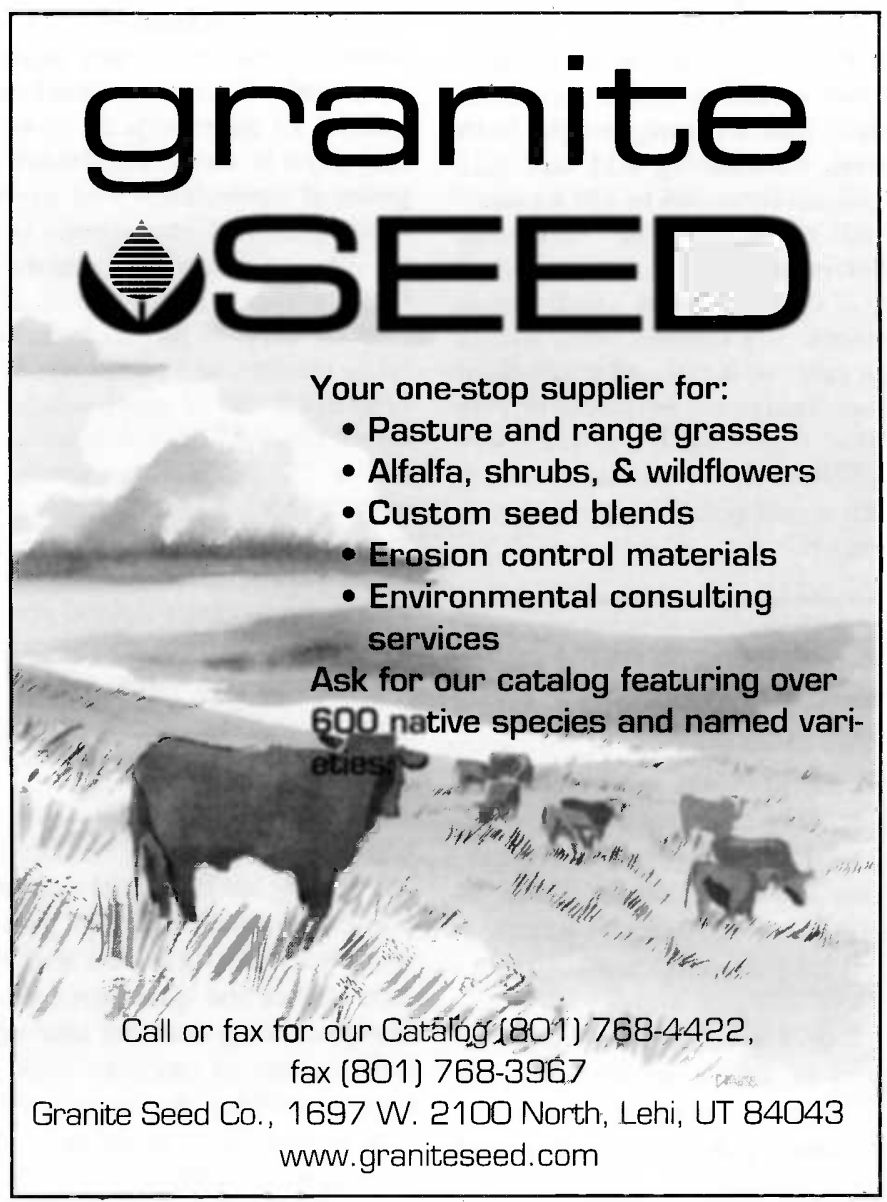

